\title{
Major Learning Contents on the Senior Administrative Personnel Overseas-Study Team of Yunnan Provincial Higher Education in 2016

\author{
Yongkun Wan
}

Yuxi Teachers College, Yuxi Municipality in Yunnan Province of China 653100

wanyongkun123@163.com

Keywords: Senior administrative personnel; Overseas-study team; Langara college in Canada; BC provincial higher education; Yunnan provincial higher education

\begin{abstract}
Yunnan Province Department of Education, Langara College and relevant institutions attach great importance to the careful planning, careful organization, the project is not only rich in content, diverse forms, including classroom teaching, case discussion, field experience \& visits, etc., and specially equipped with the class teacher and classroom translation, for all students in Canada during the study and life to provide a good environment and conditions for the smooth completion of the entire project to provide a solid organizational security. During the learning, the class committee members were responsible and positive in work, setting up good examples for all trainees who obeyed rules, followed strict requirement and studied hard. Everybody cherished honor, united and helped each other, lived a vivid school life, and successfully completed study tasks, which gave a show to the good image and fine quality of cadres and teachers from Yunnan colleges and universities.
\end{abstract}

\section{Study Group Basic Situation}

The senior personnel study team consists of administrative cadres from 13 colleges under the guidance of Foreign Cooperation and Communication Department of Yunnan Provincial Education Bureau. This group implements the mechanism that is division of responsibility under the leadership of the team head, and group leaders are responsible for the team head. In addition, our study team enhances team-culture building and puts forward the slogan of "honor, unity and liveliness" to ensure safe, efficient and high quality study. The team also sets up the posts of study commissary, culture and PE commissary, life commissary and publicity commissary who are responsible for the team members' study, after-class life organization and coordination respectively. This set of organizing mechanism has laid a solid and necessary foundation for the smooth progress of 3-month study activities.

\section{Basic Facts of Canadian Higher Education[1, 2, 3, 4, 5]}

The earliest Canadian higher education could be traced back to the Seminary of Quebec in 1663 with more than 350 years of history. As Canada was once the colony of Britain and France, its higher education is influenced by both Britain and France. With the fast development of global economy after the World War II, Canada learned from advanced educational concepts of developed countries such as Britain, France, Germany and USA and integrated its own realities to enhance educational investments. Nowadays, Canada has formed the higher educational system with multiple levels, flexible mechanisms and distinctive features, and the country now possesses a lot of world first-class colleges and universities including McGill University, the University of Toronto and the University of British Columbia, etc.

Canadian federal government consists of 10 provinces and 3 districts. Canadian educational laws definitely stipulate that provinces' or districts' governments are responsible for higher education. Canadian federal government does not set up educational department or special national higher education management institutions, with educational affairs mainly being attended by the state secretary of federal government. The federal government mainly influences higher education affairs through ways of funds and program assistance. Canada has no state-wide unified educational 
policies and stipulations, and each province has different school systems, courses and tests with every college or university being relatively independent which possesses high-degreed autonomy of running school. Canadian colleges and universities could employ teachers, set up courses and subjects and issue diplomas by themselves.

Canadian higher education has definite positioning, clear levels and divisions with its colleges or universities being divided into Career College, Community College, University College and University. Universities and colleges shoulder different tasks: universities focus on academic research, being mainly responsible for bringing up senior research and professional talents and post-graduate and undergraduate education. University colleges focus on research of applied technology, being mainly responsible for bringing up applied technical talents and undergraduates or junior college students. Community and career colleges focus on study and diploma within 2-year school study.

Canada State College and University Alliance includes 97 colleges and universities, and 175 community colleges. Each university focuses on individuation very much with different and distinctive university spirits and characteristics. All of these colleges and universities have wide range of majors with length of schooling for bachelor degree being 3 to 4 years, 5 to 6 years for some medical science degree and 2 to 4 years for master degree which is needed for getting doctor's degree with study time being 4 to 7 years. Canadian colleges and universities basically implement credit system, where students could get a degree with the pre-condition of getting enough credits.

\section{Major Study Contents}

The study period lasted from 18 September to 18 December in 2016, which was 3 months long. During this period, the major study contents involved 14 subjects, including Canadian and BC Province's higher education management mechanism, BC Province's credit transfer system, college strategic plans, college leadership strategy, etc. The study contents also included 7 outside-college university visits, 5 culture and art gallery visits and 1 aboriginal community visit. The study took class lecture, guest speech and field visits as its major forms.

During class lectures, two professors Rhordon Wikkramatileke and Martin Gerson played main roles with class-teaching forms including lecture, group discussion, on-site Q\&A and flipped class, etc. Study contents mainly included Canadian fundamental realities, Canadian higher education, Canadian colleges inner management modes and administration structure, leadership theory, strategic planning theory, management theory, higher education strategic plans, labor relations and collective agreement, academic management, student service, aboriginal education, cross-culture capacity, financial budget, course development, teaching methods and student assessment, etc.

During guest speeches, middle and senior managerial personnel from Langara College and chairpersons from other institutions successively gave introductions to European and American higher education history, Langara College's continuing education, Langara College's international education and Langara's student service, etc. Related officials from China embassy in Vancouver of Canada gave introductions to China-Canada relationship, culture difference between these two nations, etc. Furthermore, other guests including government officials, community leaders, student representatives respectively gave reports on $\mathrm{BC}$ province higher education management, credit transfer system and basic program situation of Langara students' study in China.

During field visits, the activities mainly included investigations on the colleges' inner operational mechanism, major set-up, course development program, student work and student behavior norms in the Anthropological Museum and Asian Research Center of University of British Columbia (UBC), the Innovation Center of Simon Fraser University (SFU), the Agricultural College of The University of the Fraser Valley (UFV), the library and aboriginal-culture teaching building in University of Victoria (UVIC) and British Columbia Institute of Technology (BCIT). The activity also included visits to Chinatown, Sun Yat-sen Memorial, aboriginal community of Musqueam, LaSalle College, Vancouver Art Gallery, Musqueam artist Billy's Art Gallery, Richmond Olympic Hockey Center, etc. 
During the learning process, Langara College added 4 LEAP English-study activities according to trainees' needs to stimulate everybody's study interests from different perspectives, and the pleasant study process impressed us a lot.

These studies made all team members have a deep understanding towards Canada and BC Province development history, social cultural characteristics and educational systems and made the members feel and experience Canadian local customs and practices, social economy and culture development, Canadian citizens' high quality and advanced social management concepts. In the meanwhile, everyone began to understand and think about similarities, differences and corresponding reasons among higher education management systems, teaching concepts and managerial ways between China and Canada as well as Yunnan Province and BC Province.

During the whole study process, everyone was rather interested in the mature and distinctive credit transfer system set up by BC Province and promoted in Canada or even in the world, agreeing that this system makes a clear way for lifelong-learning and embodies student-oriented educational concepts. $[6,7,8,9]$

The pre-condition of credit-transfer is based on the equivalent effects of the same courses among different schools. If courses could meet the managerial requirement of applied majors, credits then could be "transferred". Otherwise the course and credit "transfer" could not be realized if fail to meet the requirement of applied majors. In BC Province there are about $40 \%$ high school students, with credit-transfer courses, enter into different community colleges that provide fundamental theory courses and fundamental major courses for the first and second year arts and science study in universities or colleges. After completing all the credits of the first and second years, students could apply to transfer all credits into corresponding majors of other universities or colleges such as UBC, SFU, UV, etc. Of course, every university has its own admission standards and minimum GPA requirements for credit-transfer students.

This system includes not only Canadian students but also international students from different countries. BCCAT is under the specific operation of government credit-transfer committee, which possesses an online public information database recording the connections among all schools in BC Province. This is BC Province's most authoritative public credit-transfer agreement information network that support and ensure smooth operation of $\mathrm{BC}$ Province's higher education and highly-efficient output of talents.

One pre-condition is to implement credit system thoroughly. Under the assistance of teachers' guidance, credit system is a set of comprehensive teaching management system which takes course-choosing as its core to measure students study quality and quantity through GPA (grade point average) and credits. To carry out credit transfer work, it is a requirement to implement full credit system under which students could take initiatives to choose subjects, majors, courses, study process and study methods with flexible length of schooling that could be extended or shortened. Another pre-condition is that all diploma courses should go through strict quality assessment process before permission and should accept regular strict inspections.

Features of the System are:

a. Time-saving. Running time of most BC Provincial colleges and universities are flexible with being able to admit students in January, May and September, thus students could choose to enter schools according to their own situations.

b. Tuition-saving. Tuition in famous universities like UBC and SFU is expensive, and especially expensive for international students, being three time as much as that for local students. However, colleges like Coquitlam College, Alexander College and Langara College could not only provide credit-transfer courses but also charge cheap tuition.

c. Small-class teaching. Community colleges commonly take the teaching form of small-class in order to improve efficiency of credit transfer, and teaching quality could be ensured as a result.

d. Entering nearest college. Students could choose community colleges which are near to them according to their own situations to save more living costs.

BC Province's government has limited adjustment right over universities and colleges, and colleges and universities themselves are responsible for making decision and implementation of 
higher education management and teaching. Teaching quality is attended by the special coordination committee. The autonomous right of universities or colleges mainly lies in the fact that they could carry out independent admission of students, independent admission standards, independent major and research direction setting-up, independent course setting-up, independent recruiting teachers, independent joint cooperation in running schools and independent international cooperation and communication, etc. [10]

Furthermore, BC Province implements full credit system, and students have no fixed classes while they can take initiatives to choose courses according to stipulated compulsory courses and major credits. Human-oriented management concept not only embodies in educational hardware but also in the bringing-up and management of students. Students could enjoy tailored training program, multiple and free course options, study methods and enrollment time. There is no time-limit over getting diplomas, which allows students to adjust themselves according to their own situations. Full credit system are good for students choosing courses, transferring to other faculties or schools, and they can choose majors and courses according to their own interests, extend or shorten length of study, or study while working. Credit transfer is BC Provincial most important and best-featured part of its higher education system, which not only builds up the "overpass" for all-citizen education and lifelong education, but also provides different groups of people with opportunities from corresponding education to a more important degree. $[11,12]$

\section{References}

[1] Information on http://www2.gov.bc.ca/gov/content/education-training/post-secondaryeducation

[2] Information on http://langara.ca/about-langara/langara-at-a-glance/index.html

[3] G.A. Jones, translated by R.R. Lin: Higher education in Canada: different system, different perspectives(In Chinese)(Fujian Education Press, China 2007), p.1-387.

[4] Y. Guo: Features of Canadian Higher Education and Enlightenment to Reformation of Education and Teaching in Chinese Universities(MS., Tianjin University of Technology, China 2010), p.1-48.

[5] Y.B. Liu: Integration of localization and internationalization: characteristics and enlightenment of higher education development in Canada(In Chinese), Academic Forum. 233(2010)No.6, p.202-205.

[6] L. Kong and S.X. Yin: Comparative Study on Credit Accumulation and Transfer System in Europe and North America: Case Study of European Credit Transfer System and Canadian British Colombia Credit Transfer System(In Chinese), Journal of Distance Education. 210(2012)No.3, p.44-51.

[7] S.T. Zhao and M. Xu: Analysis on Credit Accumulation and Transfer System of Higher Education in Canada(In Chinese), Studies in Foreign Education. 42(2015)No.12, p.67-78.

[8] S.X. Yin: Comparative Research and Insight of Credit Transfer(In Chinese), Journal of Hubei Radio \& Television University. 35(2015)No.3, p.3-8.

[9] X.X. Wu and Y. Deng: European Credit Transfer System(ECTS) and Its Enlightenment from the Perspective of Structure and Function(In Chinese), China Adult Education. 8(2016)No.8, p.139-143.

[10]X.Y. Tang: Higher Education Development in British Columbia Province of Canada(In Chinese), Journal of Educational Institute of Jilin province. 26(2010)No.1, p.17-18.

[11]Information on http://bccat.ca/system/policies

[12]J. Chen: Canadian Credit Transfer System and Its Enlightenment(In Chinese), Vocational \& Technical Education Forum. 36(2009)No.18, p.59-61. 